\title{
Classifications of Contingent Remainders
}

\section{J.John Lawler*}

INTERESTS in real property to take effect in the future, which might or might not take effect, depending on the happening or not happening of a condition in addition to the termination of the preceding estate, were not originally found in the land law of England. The disability to control devolution of land after death in the early period of our legal history is probably sufficient explanation for the comparatively late appearance of this type of interest. ${ }^{1}$ Before 1430 , the courts recognized the validity of the first interest of this type-a remainder to the heirs of a living person. ${ }^{2}$ This was the beginning of the law of contingent remainders. Even after the recognition of these interests, however, they were seldom einployed by conveyancers until the reign of Queen Mary, who came to the throne in $1553 .^{3}$ The next two centuries saw this single type of interest develop to the point where manifold types of contingent remainders developed by the ingenuity of the conveyancers were found in practically every real property settlement. The tremendous expansion of this type of interest in real property reached its peak at the time of the great Perrin v. Blake $e^{4}$ controversy which brought about the publication by Charles Fearne of a treatise on contingent remainders in $1772 .^{\circ}$ The subject matter was deemed so important, and the treatment so masterly, that four editions were printed within nineteen years. The inmense popularity of the work has continued down to the present time.

Since this treatise marked the development of contingent remainders in England at the time of the American Revolution, it seems the best point from which to commence a study of the contingent reinainder in the United States. There very probably had been con-

*Asst. Professor of Law, University of Pittsburgh, School of Law; A.B., M.A., LL.B., University of Pennsylvania. Co-author with Gale Gates Lawler of TExAs WoRKmen's CoMpensation Law (1938); SHort History of Reax Property LaW (1938); articles in various legal periodicals.

1 The power to control the devolution of land after death did not exist prior to 32 Henry VIII (1540) c. 1.

2 Anonymous cited in Farington v. Darrel (1431) Y. B., 9 Hen. VI 23, 24.

3 See Gray, The Rule Against Perpetuities (3d ed. 1915) §134, citing 1 Jur. Soc. P. 47 .

4 (1769) $1 \mathrm{Wm}$. Bl. 672; see the discussion in LeAcH, Cases and Materiat on FUture INTEREsTs (2d ed. 1940) 132.

5 Frarne, Conttngent Rematnders and Exzcutory Devises (3d Am. ed. 1826). 
tingent remainders created in America prior to the publication of Fearne's treatise, and there had probably been litigation concerning those interests; but no cases have been found antedating that treatise. ${ }^{6}$ Fearne's treatise and Blackstone's Commentaries constituted the source material from which the American courts created our law of real property. Blackstone gave very scant treatment to contingent remainders. He divided them into two classes, gave a few examples, ${ }^{7}$ and finally stated: "It were endless to attempt to enter upon the particular subtleties and refinements, into which this doctrine, by the variety of cases which have occurred in the course of many centuries, has been spun out and subdivided; neither are they consonant to the design of these elementary disquisitions." 8 Consequently, Blackstone's work, so important as the basis of most doctrines of real property in the United States, had practically no influence on our decisions concerning contingent remainders. The basis here was found in the work of Fearne, and consequently it is an excellent poimt of departure for this study.

\section{DISTINCTION BETWEEN VESTED AND CONTINGENT REMAINDERS}

The dividing line between vested and contingent remamders was stated by Fearne as follows:

"A contingent remainder is a remainder limited so as to depend on an event or condition, which inay never liappen or be performed, or which nay not happen or be performed till after the determination of the preceding estate...."

The condition precedent to the vesting of the estate briefly mentioned here is not stated to be a condition precedent in form or a condition precedent in substance. It seems inherent in the definition, however, that Fearne means a condition precedent in substance. Throughout the pages immediately following in which he states examples of contingent remainders it is notable that in every case the condition precedent is precedent both in form and in substance, never merely in form. ${ }^{10}$ Finally in a long discussion ${ }^{11}$ of cases in which ". . a re-

${ }^{6}$ Blackgrove v. Addison (Va.1729) 20 Sir John Randolph 131 [Reported in 1 Va. Col. Dec. (1909) R 20]. Maryland is the only other state whose reports antedate the publication of Fearne and those reports show no cases of contingent remainders.

72 BL. Cosar. *169, *172.

8 Ibid. at $* 172$.

${ }^{9}$ FeARNe, op. cit. supra note 5 , at $* 3$.

$10 \mathrm{Ibid}$. at $* 5$-*9.

11 Ibid. at $* 241-* 247$. 
mainder is limited in words which seem to import a contingency, though in fact they mean no more, than would have been implied without them; or do not amount to a condition precedent, but only denote the time when the remainder is to vest in possession," 12 Fearne indicates not only by the form in which he poses the question but by his method of handling it, that by a condition which does "amount to a condition precedent" he means a condition which is precedent in substance. At no poimt does he refer to form except by "words which seem to import a contingency". From his own time until the opening years of the present century, the accuracy of this distinction was never questioned.

In the first edition of his work on the Rule Against Perpetuities Gray seems to assert two different distinctions between vested and contingent remamders. His first statement makes no attempt to define a contingent remainder, but approaches the problem by way of defining a vested remainder:

"A remainder is vested in A., when, throughout its continuance, A. or A. and his heirs have the right to the immediate possession, whenever and however the preceding estates determine; or, in other words, a remainder is vested, if, so long as it lasts, the only obstacle to the right of immediate possession by the remainder-man is the existence of the preceding estates; or, again, a remainder is vested if it is subject to no condition precedent, save the determination of the preceding estates." ${ }^{13}$

Although no attempt is made here to define a contingent remainder, there is a definition by exclusion. Any remainder which cannot satisfy this definition is a contingent remainder, since all remainders that are not vested are necessarily contingent. There is nothing in this which is inconsistent in any way with the position of Fearne.

Later in the same chapter, however, Gray makes the further statement:

"Whether a remainder is vested or contingent depends upon the language employed. If the conditional element is incorporated into the description of, or imto the gift to the remainder-man, then the remainder is contingent; but if, after words giving a vested interest, a clause is added divesting it, the remainder is vested." 14

Here Gray is discussing the same type of case as was Fearne,,$^{16}$ but note the difference in treatment. To Fearne such a remainder is con-

12 Ibid. at *241. (Italics added.)

13 GraY, op. cit. supra note $3, \$ 101,(1886)$.

$14 \mathrm{Ibid}$. at $\$ 108$.

16 FEARNE, op. cit. supra note 5 , at $* 241-247$. 
tingent only if it is 'subject to a condition precent in fact. To Gray the entire matter "depends upon the language employed". Here is the point where Gray parts company with Fearne. The point of reference is no longer to be the effect of a limitation as stating a condition in substance; it is to be whether or not the form of the language employed is conditional.

Shortly thereafter a controversy arose between Gray and Kales on this precise point. Kales first attacked the conventional method of distinguishimg between vested and contingent remainders. ${ }^{16} \mathrm{He}$ pointed out that the real question was, how far were interests by way of succession valid at common law, and how far were interests by way of interruption valid at common law. The reason for the refusal of the courts to recogmize contingent remainders at early common law was a fear that the seisin might be placed in abeyance, since a contingent remainder might conceivably come into effect either by way of succession or by way of interruption. All interests recognized up to this point were of the types that would necessarily take effect by way of succession so that there could be no abeyance of the seisin. When they did recognize contingent remainders it was under the penalty that they take effect by way of succession or not at all, thus avoiding all possibility of the dreaded abeyance of the seisin. The conventional classification has no relation to the validity of the interests. It is merely a catalogue of cases which have certain factors in common and which have certain conventional or historical names which must be explained.

In his next article Kales pointed out that in a law newly created and consistent with modern notions the distinction between vested and contingent remainders would be a distinction merely between those remainders which are certain to take effect, and those remainders that are not certain to take effect-a distinction between contimgent and non-contingent remainders. ${ }^{17}$ But we are dealing with a law that is not newly created. Our distinction is necessarily a feudal conception, just as the concept of a contingent remainder itself is

10 Kales, Future Interests in Land (1906) 22 L. Q. REv. 250.

17 Ibid. at 383. Attacks were made on this position. See Bingham, Professor Kales and Common Law Remainders (1907) 5 MTCH. L. Rev. 497; (1907) 20 Harv. L. Rev. 243. See also the rephes by Kales on the attacks on his position: Kales, $A$ Modern Dialogue between Doctor and Student on the Distinction between Vested and Contingent Remainders (1908) 24 L.Q. Rev. 301; Kales, Vested and Contingent Remainders (1908) 8 Cox. L. REv. 245. 
purely feudal. Therefore the form of the words relied on by Gray in distinguishing between vested and contingent remainders is not a true test. Kales also claimed that the exposition by Gray gave not the slightest idea of any reason for making this distinction, whereas his own exposition clears up the poimt and makes the entire thing as mathematical as Shelley's case or the Rule Against Perpetuities.

A few years later Gray published his second edition without making any change $\mathrm{i}$ his position on this point. ${ }^{18}$ In a lengthy review of this edition Kales returned to the attack. ${ }^{10}$ Then Gray publislied his third edition, with no change in his position on this point although the language of section 101 was changed. In a long discursive footnote, however, he referred to the series of articles by Kales. He continued as follows:

"Professor Kales's views have undergone some modification, but his matured opinion is contained in a correspondence with which he has favored the author. In a letter of the date of October 27,1911, he says (the italics are the author's): "The true view is that a remainder is contingent either (1) when himited on an event which may happen either before or at the time of or after the termination, whenever and in whatever manner, of the preceding particular estate, in which case it is destructible by a rule of law defeating intent; or (2) when it is subject to a condition precedent in fact and in form to its ever taking effect in possession, in which case it is inalienable at law inter vivos....'

"Two criticisms suggest themselves: First. Contingent remainders are often said to be destructible, but the expression is not strictly accurate. If a contingent remainder-man fails to come into possession, it is not because his estate is destroyed, but because he has never had an estate, but only the potentiality of an estate. When a remainder is said to be destructible, what is meant is that it needs a particular estate to support it, and that this estate is destructible. To call the remainder destructible avoids an inconvenient periphrasis, and the use of the word with this meaning is so common that it would be pedantic not to employ it. But to use the word when distinguishing vested fron contingent remainders tends to bring about that confusion of conditions precedent and subsequent which has been such a fruitful source of error, and had therefore best be avoided. Second. A contingent remainder is at common law inalienable; a vested remainder is not. But this incident, which is common to all interests on conditions precedent, does not affect the question whether a remainder is vested or contingent. In many jurisdictions contingent remainders have become alienable, but that does not prevent their continuing to be contingent remainders." 20

18 GraY, op. cit. supra note 3 (2d ed. 1906).

${ }^{10}$ Kales, Several Problems of Gray's Rule Against Perpetuities, Second Edition (1907) 20 HARv. L. REv. 192.

$20 \mathrm{GRAY}$, op. cit. supra note $3, \S 101, \mathrm{n} .3$. 
It is respectfully submitted that Gray did not effectively reply to Kales. First. Kales had objected to Gray's reliance on form, ${ }^{21}$ and to the inconsistency ${ }^{22}$-between sections 101 and 108. Gray referred this discussion not to section 108 in which he relies on the "language employed", but to section 101, which Kales considered accurate. ${ }^{23}$ Second. It will be noted that the portions of Kales' letter which were italicized by Gray, and which he purported to answer, were not the clauses stating Kales' method of distinguishing vested and contingent remainders, but were the final clauses stating the consequence of construing a remainder as contingent.

In the second edition of his textbook, Kales makes the following statement:

"A contingent remainder is thus perfectly defined by Butler: 'All contingent remainders appear to be so far reducible under one head that they depend for their vesting on the happening of an event, which, by possibility, may not happen during the continuance of the preceding estate, or at the instant of its determination. " 24

Restated briefly, the position of Gray is that any remainder is contingent if it is subject to a condition which is precedent in form. Fearne, Butler, and Kales, on the other hand, harking back to feudal principles arising out of seisin considered a remainder contingent only if there was a possibility that it might take effect by way of interruption-so that it was possible to have a remainder subject to a condition precedent in form which was a vested remainder; but any remainder subject to a condition precedent in substance was necessarily contingent. This is the reason why only Gray, of this entire group, finds it necessary to explain a result inconsistent with his line of distinction by the language: ". . . the preference of the law for vested interests has prevented this view being adopted." 25

The position taken by the American Law Institute in the Restatement of Property in distinguishing between vested and contingent remainders should be extremely important. The Restatement was the fruition of considerable thought and discussion over a period of sev-

21 Supra note 17.

22 Supra note 19.

$23 \mathrm{Ibid}$. at 194, where Kales, in criticizing section 108 states: "One may fairly ask why the learned author inakes the test the inere form of words, when his own definition furnishes a sufficient foundation for the distinction which he wishes to draw." (Italics added.)

24 Kates, Estates, Future Interests (2d ed. 1920) \& 29.

$20 \mathrm{GRAX}$, op. cit. supra note $3, \S 105$. 
eral years by the most eminent scholars, practitioners and judges. The section on classification of remainders, however, was not considered and discussed over a period of years. It appeared for the first time in the "Proposed Final Draft" in 1936 and was adopted without discussion on the part of members at the annual meeting. ${ }^{26}$ The distionction is stated as follows:

"Classification of Remainders.

A remainder can be

(a) indefeasibly vested; or

(b) vested subject to open; or

(c) vested subject to complete defeasance; or

(d) subject to a condition precedent." $2 \pi$

The section as stated serves two purposes simultaneously. Remainders are classified into those subject to a condition precedent and those not subject to a condition precedent. Remainders not subject to a condition precedent are then subdivided into types (a), (b), and (c) depending on the comparative certainty of enjoyment. The method of employing that factor here and the "Note to Terminology" 28 clearly indicate that originally there was no thought of employing certaimty or uncertainty of enjoyment in distinguishing between vested and contingent remainders, since admittedly that factor has no bearing on the problem. The name "contingent remainder" appears only in the "Note to Terminology" but as a "remainder subject to a condition precedent" the interest seems to remain as it was in the time of Fearne. The new name, which is a more accurate description of the interest, seems desirable since it removes some slight possibility of confusion.

One of the limitations of the black letter technique of presentation is that the black letter sections constitute a mere skeletal system. The somatic content is found in the comments. There are two comments to this section which are pertinent to the present discussion. The first is the "Comment on Clause (b)" referring to a remainder not subject to a condition precedent:

"Remainder vested subject to open-Certainty of enjoyment of some share. When a remainder is vested subject to open, it is possible to point to

2613 Proc. American Law Institute (1936) 117. The only reference to section $199 \mathrm{E}$ is on 195 . No notice was taken of this problem.

27 P.F. D. (Am. L. Inst. 1936) §199E; Property RestateMENT (Am. L. Inst. 1936) $\$ 157$.

281 1bid. at 542 . 
a person and to say that such person would take, if all interests including a prior right to enjoyment of the thing should now end. Furthermore this person is certain to acquire a present interest in some part of the affected thing at some time in the future, and is also certain to be entitled to retain permanently thereafter the present interest so acquired." 29

Standing alone this statement is not subject to any exception. It does not purport to be definitive or exhaustive but is merely an illustration of the common type of remainder which is vested subject to open. The second comment pertinent to the present discussion is the "Comment on Clause (d)" referring to a remainder subject to a condition precedent:

"Remainder subject to a condition precedent-Uncertainties. When a limitation creates a remainder and it is not possible to point to any person and to say such person would take, if all interests including a prior right to a present interest should now end, this remainder is subject to a condition precedent. This uncertainty distinguishes this type of remainder from those vested subject to open ... and from those vested subject to complete defeasance...."30

In form this comment is possibly intended to be definitive and exhaustive, but whether or not that is true the comment standing alone is rather misleading in that it gives the impression that the distinguishing factor between vested and contmgent remainders is the presence of a person to whom one can point as the next taker. When the second sentence of this comment is combined with the "Comment on Clause (b)" stated above the common law distinction has been lost entirely.

The third and fourth sentences of the "Comment on Clause (d)" would seem to restrict the entire comment to the common law distinction:

"Sometimes the uncertainty proceeds from the necessity, under the terms of the limitation, for some stated event to occur before a known person could have a certainty of future enjoyment.... Sometimes the uncertainty is still more pervasive in that the fulfillnent of the condition precedent inust occur before any person will exist who could take the remainder interest." 31

It seems clear that the American Law Institute had no intention of departing from the common law in this instance, since when they did nitend to do that they made their intention perfectly clear, ${ }^{32}$ but

29 Ibid. at 551.

30 Ibid. at 561 .

31 Ibid.

32 Ibid. at $\S \S 240, b, 240$, c, 240, d. 
a careless reading of these two comments would seem to indicate that the New York statutory definition is now the distinction of the $R e$ statement. Under that definition it has been held that a remainder which would clearly be contingent according to any common-law distinction was vested..$^{33}$ In the course of the opinion Judge Woodruff said:

"... if you can point to a human being and say as to him, 'that man or that woman, by virtue of a grant of a remainder, would have an immediate right to the possession of certain lands if the precedent estate of another therein should now cease,' then the statute says, he or she has a vested remainder." 34

This language is merely paraphrased in the two comments quoted. The intention of the American Law Institute is probably even clearer since a later section dealing with a construction problem embodies the common-law distinction. ${ }^{35}$ The Restatement distinction, then, would seem to be that of the common law, but the statement in the two comments quoted is so equivocal that it cannot be relied upon for general use and has caused at least one court to err on this point. ${ }^{30}$

Simes, in his very recent textbook refuses to commit himself by making any definite statement of a standard; but weakens to the point of indicating that a remainder is contingent if it is (a) to an unascertained person or (b) subject to a condition precedent. ${ }^{37}$ This is, of course, another form of words expressing the same distinction as that adopted by the Restatement of Property, in the first black letter section above.

A remainder, or for that matter, any future interest, except the right of reentry for condition broken (recently dubbed the power of termmation) defies any attempt to place it within conventional juristic classifications. The holder of a remainder has certain rights, privileges, powers and immunities, and is subject to certain no-rights, liabilities and disabilities. If his remainder is contingent, he will have fewer of those legal relations than if it is vested, but he will have the potentiality of acquiring those additional relations on the happening

33 Moore v. Littel (1869) 41 N.Y. 66.

34 Ibid. at 76.

35 Property Restatearent T. No. 9 (Am. I. Inst. 1938) \$250.

36 Overbrook Heights Bldg. \& Loan Ass'n v. Wilson (1939) 333 Pa. 449, 5 A. (2d) 529. See also Lawler, Remainder Conditioned Upon Survivorship (1940) 15 TeMpre L. Q. 107, 126; Vance, The Restatement of the Law of Property (1937) 86 U. OF PA, L. REv. $173,176$.

37 I StMES, THE LAW OF FutURE INTERESTS (1936) $\S 71$. 
of the event. These, however, are the consequences of the distinction, and not the distinction itself, which must be the line of demarcation between "vestedness" and "contingent-ness."

Dean Fraser states the distinction as follows: "If there is a person who has an unconditioned liability to have a possessory estate on the ending in any manner of the prior estate, the remainder is vested; if there is not a person with this unconditioned liability, the remainder is contingent." 38

The principal difficulty with this analysis seems to be the total lack of any person on the opposing side of the situation to hold the correlative "power". As is stated so neatly by the Restatement: "Legal relations in our law exist only between persons. There cannot be a legal relation between a person and a thing or between two things." ${ }^{39}$ And at another point the following statement is made: "The relation indicated by the word 'power' may also be stated from the point of view of the person whose legal relation is thus liable to be changed. This subjection of the second person to having his legal relation affected by the conduct of the person having the power is a 'liability'...." 40

For example, in a grant to $A$ for life, remainder, if $A$ die leaving surviving issue, to such issue and their heirs forever, but should he die without leaving surviving issue, then to $C$ and his heirs forever, the remainder to $C$ would be contingent according to all methods of determining whether a remainder is vested or contingent. If in accord with Dean Fraser's analysis we decided that $C$ has a "conditioned liability", where is the correlative power? Certainly not in $A$. He has merely a life estate, and no ability to change the legal relations of $C$ by giving him a possessory estate, which would be necessary under the Fraser analysis. Certainly the power is not in the "surviving issue", since they are not yet determined.

As Hohfeld states the position: "A change in a given legal relation may result (1) froin some superadded fact or group of facts not under the volitional control of a human being (or human beings); or (2) from some superadded fact or group of facts which are under the volitional control of one or more human beings. As regards the

881 Fraser, Cases and Readings on Property (1932) 262.

39 Property Restateanent T. No. 1 (Am. L. Inst. 1929) 11. Cf. HoHrerd, FUNDAatentai Legat Conceptions (1923) 75, 76; Holland, The Elements of JurispruDeNce (8th ed. 1896) c. 8; Noyes, The Institution of Property (1936) 288, 289.

10 Restatedent, op. cit. supra note $27, \S 3$ a. 
second class of cases, the person (or persons) whose volitional control is paramount may be said to have the (legal) power to effect the particular change of legal relations ...."

This is quite obviously a situation of the first type where the change in legal relations will result (if at all) from the addition of a fact-the happening of the event-which is not under human volitional control. The death of $A$ without surviving issue or leaving surviving issue will change the legal relations of $C$ by definitely giving or withholding a possessory estate. Clearly there is no liability here, in the accurate sense of that term. The group of scholars engaged in restating the law of real property (of which Dean Fraser was a member) undoubtedly recognized this difficulty. It is notable that in defirning the various future interests they ignored the terminology to which they had committed themselves in their introduction, except in the one case of the right of entry for condition broken, which they called a "Power of Termination", the accuracy of which is also questionable. ${ }^{42}$

There had, indeed, been a suggestion by Hohfeld that the distinction between vested and contingent remainders is that the holder of a vested remainder has actual legal relations, whereas the holder of a contingent remainder has only potential legal reations. ${ }^{43}$ Even in stating the suggestion however, it was recognized that it was subject to many qualifications, since, from the time of Fearne the holder of a contingent remainder had certain actual legal relations, namely, he had the power to release his interest, the power to devise it, and the power to alienate it by certain modes of conveyance. ${ }^{44}$ This necessity for qualifying a terminology which in other situations is extremely accurate and helpful makes it inappropriate in this situation.

To create a valid distinction between two concepts, it is first necessary to establish one concept as a polar element to which the other concept can be compared, always being careful to keep the two concepts in the same phase. Disregard of the necessity of polarizing one concept results in a definition of one or the other concept with the resulting danger that the definition will prove either to be not sufficiently inclusive or too broad. Disregard of the necessity of keeping the concepts in the same phase results in the confusion found in

41 HoHrexd, op. cit. supra note 39 , at 50 .

42 RestateareNT, op. cit. supra note $27, \$ 155$. See with reference to this point, HOHFELD, op. cit. supra note 39, at 54, 55; Vance, loc. cit. supra note 36.

43 HOHFELD, op. cit. supra note 39 , at 112 .

44 FEARNE, op. cit. supra note 5 , at $* 365, * 366, * 367$. 
Gray's reply to Kales where the distinctions and the consequences were confused.

A vested remainder is postponed from enjoyment only by the existence of prior vested estates or estates of enjoyment. The vested remainder will normally succeed to enjoyment but there are exceptions as in the vested remainder limited to the life of the first taker. This normal characteristic of the vested remainder has occasionally led to distinguishing between vested and contingent remainders on the basis of relative certainty of enjoyment. The exception noted above is sufficient in itself to nullify the validity of such a distinction since it prevents the establishment of the vested remainder as a polar element in this phase.

The only unobjectionable stateinent that can be made of a vested remainder seems to be that it is a remainder which is not subject to any condition precedent to vesting in enjoyment other than the termination of the preceding estates (save, of course, its own continued existence). A contingent remainder can then be distinguished from the vested remainder as a remainder which is subject to some condition precedent in substance other than the termination of the preceding estate or estates to becoming a vested remainder or to vesting in enjoyment (and, of course, to the condition precedent of its own continued existence). In other words, in a vested remainder there is an unconditional, or actual, privilege of future enjoyment. In a contingent remainder there is a conditional, or potential, privilege of future enjoyment. (The words actual as opposed to potential seem to convey the idea much better than the words unconditional as opposed to conditional). In both cases there are corresponding norights, which are multital. The distinction, then, lies not in the relative certainty of enjoyment, but in the relative present legal relations of the holders as against people in general with reference to enjoyment.

\section{CIASSIFICATIONS OF CONTINGENT REMAINDERS}

Fearne devoted two-thirds ${ }^{45}$ of his treatise to distinguishing contingent remainders from vested remainders, and classifying thein anong themselves. The last one-third ${ }^{46}$ of his treatise he devoted to a description of what he called the "qualities" of a contingent remainder. In this last third he inentioned only alienability, descendi- 
bility, devisability, and destructibility. Apparently he considered contingent remainders different from vested remaimders in consequences only with reference to those four points.

Fearne divided contingent remainders into four classes which were mutually exclusive, and which have become classical in the law of real property. Strangely enough, however, these classes did not have, nor were they apparently intended to have, any jural consequence. In the last third of the book dealing with the consequences of construmg a remainder as contingent rather than vested, no reference is made to the four classes. Jerome Frank would say, no doubt, that the invention of the four classes was merely a symptom of the "verbomamia" which has so long afflicted the common law-a classification, merely for the purpose of intellectual satisfaction, leading the classifier to feel that the inatter was now settled.7 These troublesome things had been given invocatory names, and were now under control. Despite a feeling of this sort with reference to the famous four classes, however, due to the long acceptance which they have enjoyed in the courts, and in legal literature, they cannot be ignored. Let us examine them at some length. As Fearne stated them they were as follows: ${ }^{48}$

" 1 . Where the remainder depends entirely on a contingent determination of the preceding estate itself;-As if $A$. makes a feoffment to the use of $B$. till $C$. returns from Rome, and after such return of $C$. then to remain over in fee; here the particular estate is limited to determine on the return of $C$., and only on that determination of it is the remainder to take effect; but that is an event which possibly may never happen; and therefore the remainder, which depends entirely upon the determination of the precedimg estate by it, is dubious and contingent.-So where a fine was levied to the use of $A$., and the heirs male of his body, until he the said $A$. should do such a thing; and after such a thing done by the said $A$. to the use of $B$. in tail: $A$. died without issue, and without performing the condition; and it was adjudged the remainder was contingent, and never took place.

" 2 . Where some uncertain event, unconnected with, and collateral to the determination of the preceding estate, is, by the nature of the limitation, to precede the remainder;-As if a lease be made to $A$. for life, remainder to $B$. for life, and if $B$. die before $A$. remainder to $C$. for life; lere the event of $B$.'s dying before $A$. does not in the least affect the determination of the particular estate, nevertheless it must precede and give effect to $C$.'s remainder; but such event is dubious, it may or may not happen, and the remainder depending on it is therefore contingent.-So if lands be given to $A$. in tail, and if $B$. come to Westminster hall such a day, to $B$. in fee; here $B$.'s

47 FRANK, LAW AND THE MODERN MIND (1930) 63.

18 FEARNE, op. cit. supra note 5 , at $* 5-* 9$. 
coming to Westminster hall has no connection with the determination of $A$.'s estate; but as it is an uncertain event, and the remainder to $B$. is not to take place unless it should happen, such remainder is therefore a contingent remainder.

"3. Where a remainder is himited to take effect upon an event, which, though it certainly must happen some time or other, yet may not happen till after the determination of the particular estate;-As if a lease be made to $J$.S. for life, and after the death of $J . D$. the lands to remain to another in fee; now it is certain that J.D. must die some time or other, but his death may not happen till after the determination of the particular estate by the death of $J . S$., and therefore such remainder is contingent.-So in the case of a lease for life to $A$., and after the death of $A$. and $M$., the remainder to $B$. in fee, this is a contingent remainder; for the particular estate being only for the hife of $A$., and the remainder not commence till after the death of $A$. and $M$., if $A$. die before $M$. the particular estate will end before the remainder can commence; which is very possible, and therefore such remainder is contingent.-So if a feoffment be to the use of $A$. for 21 years if he shall so long live, and after his death to the use of $B$. in fee; here $A$. may survive the 21 years; if he should, the particular estate would determine before the remainder conld commence, and therefore such remainder is contingent; and being so, is void, for want of a preceding freehold to support it, as will appear hereafter.

"4. Where a remainder is limited to a person not ascertained, or not in being at the time when such himitation is made;-As if a lease be made to one for hife, remainder to the right heirs of J.S.; now there can be no such person as the right heir of J.S., until the death of J.S. (for nemo est haeres viventis,) which may not happen till after the determination of the particular estate by the death of the tenant for life, therefore such remainder is contingent.- So where a remainder is limited to the first son of $B$., who has no son then born; here $B$. may never have a son, or if he should, the particular estate may determine before the birth of such son, therefore this remainder is contingent.-So if an estate be limited to two for life, remainder to the survivor of thein in fee, the remainder is contingent, for it is uncertain who will be the survivor."

\section{Fearne's First Class}

With reference to the first class stated above, the first notable point is the similarity of a remainder of this type to a shifting executory interest. Fearne recognized this close similarity, and devoted considerable space to pointing out the distinction between remainders of this class and the corresponding executory interests. The executory interest terminates a particular estate before its natural termination. This type of contingent remainder takes effect after the natural termination of an estate which ends on the happening of a contingency. 
Fearne then states: "Contingent remainders appear to have been generally distributed into three kinds only; namely the three last specified in the above division of them. But I think it is obvious that the first sort above noticed, cannot be brought within any one of the other three descriptions...."49

The only reason, then, for the invention of the first class was the failure of the second and third classes to cover this precise situation. As those classes are stated it is clear that this situation is not covered. It will not fit into the second class because that requires an event collateral to the particular estate. The third class is not available because the event is not certain to occur at some time or other. The fourth class does not apply for obvious reasons.

Nevertheless Fearne could cite only two cases falling within this first class. ${ }^{50}$ It would seem then, that the first class is so small as to have no practical importance. Very probably an excellent reason for this condition is the similarity of remainders of this class to executory limitations. A draftsman who was desirous of creating a future interest subject to a condition where he could use either a contingent remainder of this type or an executory interest would naturally enough choose the executory interest as the vehicle of the interest due to the many advantages of the executory interest over the contingent reinainder at common law.

\section{Fearne's Second and Third Classes}

These two classes are clearly inutually exclusive and unobjectionable. The majority of contingent remainders fall within these classes. In both of thein the person is certain but the event uncertain. In one the event is certain to happen at some time, but the time of the happening is uncertain. In the other it is not certain that the event will ever happen.

\section{Fearne's Fourth Class}

It is a truism accepted by all jurisprudential scholars that all legal relations exist only between persons. As stated by Kant: “... if a man were alone in the world he could properly hold or acquire nothing as his own; because between himself, as a person, and all

19 Ibid. at *9.

50 Myers v. Weiner (1901) 69 Ark. 319, 63 S.W. 52, concerns a remainder of this type. 
other external objects, as things, there is no relation," 51 or to repeat the clear statement of the American Law Institute, "Legal relations in our law exist only between persons. There cannot be a legal relation between a person and a thing or between two things." 52 In light of this let us examine Fearne's fourth class of contingent remainders. His fourth class is defined as consisting of remainders where the person to take is not ascertained or not in being. He gives three illustrations, first, "... to one for life, remainder to the right heirs of J. S. ..."; second, "... a remainder to the first son of $B$., who has no son then born ...."; third, "... to two for life, reinainder to the survivor of thein in fee...." The first two illustrations are clearly the same; both run to persons as yet unborn.

The third illustration clearly seems to be out of place, however. In the first two it is inpossible to point to any person and say that there is a possibility that he may some day have the property in fee sinple. In the third illustration, however, definitely one of the two will survive in the normal course of events. It is possible then, to say that either $A$ or $B$ will soine day hold this property in fee simple. Since Fearne classifies reinainders, throughout, on the nature of the condition, it seems that this third illustration does not belong under the fourth class at all. Fearne speaks of this illustration as if it were a single interest to go to an unascertained person. It is actually an interest certain to go to one of two ascertained persons. No question of devise or descent can arise due to the survivorship requirement, but if $A$ conveyed by one of the methods which by the time of Fearne had been approved for conveying contingent remainders, and subsequently survived $B$, is there any question but that $A$ 's grantee would take the property? But $B$ could have inade a similar conveyance, although in the eventuality supposed his grantee would have taken nothing, not because $B$ had nothing, but because the event did not happen. Had $B$ survived $A$, the grantee of $B$ could have taken, therefore $B$ clearly had something to convey. Does this not indicate that this illustration is really not one contingent remainder, but two alternate contingent remainders - a remainder in fee simple in $A$, if he survives $B$, and a reinainder in fee simple in $B$, if he survives $A$ ? It

D1 KANT, RECHTSLEHRE, I.2.11. The translation given here is taken from NoYes, op. cit. supra note 39, at 290. Cf. AUSTIN, LECTURES ON JURISPRUDENCE (3d ed. 1869) 290, 291, 357; HOHFELD; HOLLAND, both loc. cit. supra note 39; KOCOUREK, JURAL REIATIONS (1927) 54; SALIIOND, JURISPRUdENCE (8th ed. 1930) 241, 242; TERRY, SOMNE LEAding PrINciples of ANglo-A ArERICAN LAW (1884) 97, to the same effect.

62 Restatearent, loc. cit. supra note 39. 
would certainly seem that Fearne could better have used this illustration under his second class of contingent remainders. Indeed one of his illustrations under his second class is "... to $A$. for life, remainder to $B$. for life, and if $B$. die before $A$. remainder to $C$. for hife." If we change the letter $C$ to the letter $A$, the entire limitation shows a striking similarity to the interest of either of the two who take the jomt life estates in this illustration.

Accepting the first two illustrations as really applicable to Fearne's fourth class of contingent remainders, let us examine that class rather closely.

The interest in real property which we call a contingent remainder was, at the time of Fearne, a bundle of actual rights and privileges (e.g., an exclusively equitable right and privilege against waste), powers (e.g., a concurrent power to alienate), and liabilities (e.g., a concurrent liability to the loss of all legal relations by the exercise by the holder of the particular estate of his privilege and power to make a tortious feoffment), and an additional bundle of potential rights, privileges, powers, and immunities, equivalent to the actual rights held by a vested remainderman. ${ }^{53}$

Kant, in the extract quoted above, was thinking, apparently, of a situation in which a person by virtue of occupancy had some factual relation to an external object, but due to a lack of persons against whom that factual relation could be made effective, was conceived of as having no legal relations with reference to that object. This is the obverse situation. Here there is an external object-a tract of land-with reference to which there is a potentiality that there may be in the future a person with many legal relations, both "paucital" and "multital". 54 There is no lack of persons against whom such a relation could be made effective- the holder of the particular estate would be on the opposite side of the paucital relations, and all persons generally, on the opposite side of the multital relations. There is, however, no person in whom those relations can inhere at present.

53 HoHFELD, op. cit. supra note 39 , at 112, 113.

54 Ibid. at 72: "A paucital right, or claim (right in personam), is either a unique right residing in a person (or group of persons) and availing against a single person (or single group of persons) ; or else it is one of a few fundamentally similar, yet separate, rights availing respectively against a few definite persons. A inultital right, or claim (right in rem), is always one of a large class of fundamentally similar yet separate rights, actual and potential, residing in a single person (or single group of persons) but availing respectively against persons constituting a very large and indefinite class of people." 
The force of the logic is equally strong in both sitnations. If there are no legal relations in the first situation, there are none in the second.

Cannot we say, however, that the stating of Fearne's fourth class of contingent remainders is merely a conventionalized method of stating certain limitations on the holder of the particular estate? If so, what are these limitations? If they exist at all they should exist in the same number and the same force as those placed on the holder of the particular estate by the existence of a contingent remainder of either of the first three classes. The holder of the particular estate should, for example, be subject to an exclusive no-right so far as waste is concerned. But can we conceive of him as being subject to such a no-right where there is no one who can file a bill seeking an injunction? Clearly not. For the same reason there are no other limitations imposed on the holder of a particular estate by the existence of a contingent remainder of the fourth class. Clearly then, we cannot say that the stating of the fourth class of Fearne is merely a conventionalized method of stating certain limitations on the holder of the particular estate.

Since the creation of a contingent remainder of this class does not establish any legal relations either actual or potential, it would seem that we are forced to reach the conclusion either that, juristically, contingent remainders of Fearne's fourth class are not presnetly existing legally protected interests, or that the assumption of our jurisprudential scholars that there can be no "rights"- that is legally protected interests-apart from legal relations is completely erroneous. The logical difficulty seems to arise from the basic premise of all analytical jurisprudence scholars that law necessarily involves an element of actual or potential restramt. Consequently the material employed in analysis and classification consists of situations where $A$ can compel activity or forbearance on the part of $B$. A contingent remainder linited to persons as yet unborn or unascertained does not lend itself to analysis and classification in this manner. But this type of remainder has been recognized by the courts for five centuries. It has been employed by innumerable grantors, settlors, and testators to control the ultimate devolution of their property one generation further within a family line. Consequently, we should not ignore this remainder because it is not amenable to analytical jurisprudential classification as a legally protected interest. Let us rather recognize it as the courts do-a potentiality (sometimes requiring 
the appointment of a trustee or guardian) ${ }^{55}$ that a legally protected interest may arise in the future.

Gray in his Rule Against Perpetuities needed and inade no classification of contingent remainders, since, for his purpose, they were all treated identically. So long as the remainder was contingent, Gray considered it subject to the Rule Against Perpetuities. ${ }^{56}$ The question of whether or not contingent remainders varied as between themselves could not arise.

In his text book on future interests, Kales made no classification of contingent remainders, apparently considering such a classification pointless and unnecessary. In giving examples of contingent remainder, for illustrative purposes, he stated limitations creating contingent remainders of Fearne's second, third and fourth classes, but he did not refer to them as classes. ${ }^{57}$

It is likewise true that the Restatement makes no classification of contingent remainders. For its purpose, vested remainders were divided into three classes, corresponding to the degree of certainty that they would come into enjoyment. ${ }^{53}$ Contingent remainders were lumped together as all remainders subject to a condition precedent.

Simes states: "It is likewise true that contingent remainders differ among themselves." He then proceeds to state the Fearne classification. Continuing, he states: "Perhaps a more practical classification is that indicated by Blackstone in the following language: 'Contingent or executory remainders (whereby no present interest passes), are where the estate in remainder is limited to take effect, either to a dubious and uncertain person, or upon a dubious and uncertain event; so that the particular estate may chance to be determined and the remainder never take effect.' Thus we have a division of contingent remainders into two types: (a) Where the remainder is to an ascertained person on a condition precedent; and (b) where the remainder is to an unborn or nonexistent person. Such a classification has frequently been made by the courts, and has been used in comection with questions of the alienability of future interests." 50

It is submitted that the "more practical classification" of Blackstone used by Simes is both unreasonable and impractical. First, it

55 Miller v. Texas \& Pac. Ry. (1890) 132 U. S. 662; Restatement, op. cil. sutpra note $27, \S 182$.

56 GraY, op. cit. supra note $3, \$ 284$ et seq.

57 KaIES, op. cit. supra note 24, $\$ \$ 27,309$.

68 REsTateMENT, loc. cil. supra note 27.

591 Stares, op. cit. supra note 37, \$ 58, quoting from 2 BL. Comas. *169. 
applies to "contingent or executory remainders (whereby no present interest passes)" which completely ignores the facts. Even at the time of Blackstone it had been recognized that the holder of a contingent remainder had certain actual legal relations (a limited number of them to be sure), and a great many potential legal relations. ${ }^{60}$ Obviously, then, soine "present interest" had passed. Second, this classification divides all contingent remainders into two classes, viz., reınainders of Fearne's fourth class, and all other remainders. Of all conceivable problems in which a classification of this type would have no utility, the clearest would seem to be alienability problems. If there is no person holding an interest it is impossible to raise any problem concerning the power of this non-existent person to alienate. Simes, however, finds that this "classification has frequently been made by the courts" (citing five Illinois decisions) "and has been used in connection with questions of the alienability of future interests."

\section{VALIDITY OF THE CLASSIFICATIONS}

Any classification within the realm of law is an exercise of a form of analytic jurisprudence, and can be justified only if it aids us in solving problems. Classification, then, to be significant, requires the establishment of categories (a) which are mutually exclusive; (b) which embrace, in one or another of the categories, all conceivable cases; and (c) which entail consequences which vary with the respective categories. Of course this variance in consequences must be of moment in the purpose involved, since some classifications will be perfectly valid and effective for one purpose, and completely invalid and meffective for another purpose. For example, real estate agents frequently classify leaseholds and fees simple in which they deal into commercial property and residential property. For the purposes of the real estate business, namely, obtaining purchasers, the classification satisfies the third requirement mentioned above, just as certainly as it satisfies the first two. Such a classification is of no importance juristically, although it is still a classification the categories of which are (a) mutually exclusive, and (b) embrace all conceivable cases. The variance in consequences which made it a satisfactory classification for the purposes of the real estate business do not exist juristically.

60 Supra note 36.

61 1 Snars, op. cit. supra note $37, \S 58$. 
We have, in this study, dealt with two kinds of classifications, those setting up a distinction between vested and contingent remainders, and those setting up distinctions between contingent remainders as among themselves. With reference to the first type of classification, the distinction between vested and contingent remainders clearly establishes categories (a) which are mutually exclusive, viz., remainders which are not subject to any condition precedent to vestimg in enjoyment other than the termination of the preceding estate (actual privilege) and remainders which are subject to some condition precedent in substance in addition to the termination of the preceding estate to becoming vested remainders or to vesting in enjoyment (potential privilege). Those two categories also (b) embrace all conceivable cases which may arise with reference to the manner in which the remainder takes effect, which is the point of reference of the distinction. They also (c) entail consequences which vary with the respective categories. For instance, if a remainder falls into the category of contingent it is destructible. A remainder that falls into the category of vested is not destructible. At the time of Fearne, then, this classification between vested and contingent remainders was absolutely valid, and a useful classification within the standard above discussed. So far as this classification is concerned $m$ the United States at the present day, it still satisfies the requirement of (a) being mutually exclusive, and (b) embracing all conceivable cases. Whether or not it (c) entails consequences varying according to the category, other than the existence of the condition precedent, requires a detailed study of the applicable statutes and case law which it is hoped can be completed in the near future.

With reference to the second type of classification, the distinction between contingent remainders among themselves clearly established categories (a) which are mutually exclusive, and (b) which embrace all conceivable cases, whether we take the distinction established by Fearne, or that established by Blackstone. Unless variations in legal consequences are predicated on these distinctions, however, the distinctions, and the resulting classifications are merely intellectual calisthenics. No purported classification which fails to classify can be dismissed as harmless. Seemingly well developed classifications are too apt to mislead. Neither Fearne nor Blackstone made any attempt to predicate consequences upon the classification. Blackstone made his classification merely in passing, and by his own statement did not intend that it be taken as the result of full reflec- 
tion. In all of Fearne's classes the distinguishing factor is the nature of the condition. In each situation, the holder of the contingent remainder (save in his fourth class where there is no "holder") has a group of actual and potential relations, the potential relations being subject to a condition precedent, the nature of this condition determining the class within which the remainder is placed. It is a classification of the same type as that between commercial property and residential property. The first two requirements of a valid classification are satisfied, but the third requirement is not met. There is consequently, a difference only in the non-essential as opposed to the operative facts, entailing no variance in consequences.

Contrary to the distinction between contingent and vested remainders, which was valid when established, the distinction between contingent remainders ainong themselves never did have any vahdity, and should be completely disregarded in the interests of clarity in the law of real property. 